BASIC RESEARCH

\title{
Increased adrenomedullin immunoreactivity and mRNA expression in coronary plaques obtained from patients with unstable angina
}

\author{
T Ishikawa, K Hatakeyama, T Imamura, K Ito, S Hara, H Date, Y Shibata, Y Hikichi, Y Asada, T Eto
}

Heart 2004;90:1206-1210. doi: 10.1136/hrt.2003.017921

See end of article for
authors' affiliations
.....................
Correspondence to:
Dr Kinta Hatakeyama, First
Department of Pathology,
Miyazaki Medical College,
University of Miyazaki,
5200 Kihara, Kiyotake,
Miyazaki 889 -1692,
Japan; kpathol@
fc.miyazaki-u.ac.jp
Accepted 4 December
2003

\begin{abstract}
Objective: To examine the expression and localisation of adrenomedullin in human coronary atherosclerotic lesions from patients with unstable angina (UAP) and stable angina (SAP), and to study the relation between adrenomedullin expression and plaque instability.

Design: A retrospective observational study.

Patients: Directional coronary atherectomy samples were obtained from 15 patients with UAP and 12 with SAP.

Methods: The localisation of adrenomedullin was examined by immunohistochemistry, and adrenomedullin mRNA expression was measured by quantitative polymerase chain reaction. Results: Adrenomedullin immunoreactivity was preferentially localised in macrophages, intimal smooth muscle cells, and proliferated microvessels. The mean number of adrenomedullin positive cells in five high power fields $(\times 400)$ per specimen was higher in patients with UAP than in those with SAP (mean (SEM), 110 (13) v 76 (7); $p<0.05)$; and the ratio of adrenomedullin positive to total cells was higher in patients with UAP (43.0 (2.2)\% v 34.2 (2.0)\%; $p<0.01)$. More adrenomedullin mRNA was expressed in the plaque of patients with UAP than in those with SAP $(60.4$ (16.9)\% $\vee 9.7$ (3.3)\%; $p<0.01)$.

Conclusions: The findings suggest that adrenomedullin is involved in the development of atherosclerosis and plaque instability in human coronary arteries, in an autocrine or paracrine manner.
\end{abstract}

A drenomedullin is a hypotensive and vasorelaxing peptide that was originally isolated from human phaeochromocytoma tissue. ${ }^{1}$ The peptide consists of 52 amino acids with an intramolecular disulfide bond forming a ring structure of six residues, and is widely distributed in tissues and organs, especially those of the cardiovascular and endocrine systems. ${ }^{12}$ Endothelial cells, vascular smooth muscle cells, and cardiac myocytes are considered to be the main sources of adrenomedullin in the cardiovascular system. ${ }^{1}$ We have shown that adrenomedullin immunoreactivity is localised in various medial vascular smooth muscle cells of arteries, veins, and lymphatic channels, and that immunoreactivity is intense, especially in the walls of small vessels (so called "resistant vessels"), suggesting a crucial role of adrenomedullin in blood pressure regulation. ${ }^{3}$ Macrophages and vascular smooth muscle cells play pivotal roles in atherogenesis. ${ }^{4}$ In vitro studies have shown that adrenomedullin production is augmented by inflammatory cytokines. ${ }^{25}$ In addition, inflammatory cytokines also play important roles in atherogenesis and plaque instability. ${ }^{6}$ These findings suggest that adrenomedullin is involved in the development of atherosclerosis and plaque instability. However, few studies have examined adrenomedullin in human atherosclerotic lesions. We therefore examined the expression and localisation of adrenomedullin in human coronary atherosclerotic lesions from patients with unstable (UAP) and stable (SAP) angina, and studied the relation between adrenomedullin immunoreactivity and plaque instability.

\section{METHODS}

\section{Patients}

The study population of 27 consecutive patients ( 25 men, two women; mean (SEM) age, 63 (2) years) underwent directional coronary atherectomy at the cardiac catheterisation laboratories in Miyazaki Medical College Hospital (Miyazaki, Japan), Miyazaki Medical Association Hospital (Miyazaki, Japan), and Shin-Koga Hospital (Kurume, Japan) between May 1999 and March 2001. Twenty seven atherectomy specimens were derived from proximal lesions in the left anterior descending coronary artery $(n=23)$, right coronary artery $(n=2)$, and left main trunk $(n=2)$. Twelve of the 27 specimens were from patients with SAP and 15 from patients with UAP. Angina at rest, new onset angina (within one month), or accelerated angina caused by exertion was clinically defined as UAP.

Hypertension, hyperlipidaemia (total cholesterol $>5.70$ $\mathrm{mmol} / \mathrm{l}$ ), hyperuricaemia (plasma uric acid $>0.42 \mathrm{mmol} / \mathrm{l}$ ), diabetes mellitus, smoking, obesity (body mass index $\left.>30 \mathrm{~kg} / \mathrm{m}^{2}\right)$, and a family history of coronary artery disease (parent, sibling, or child with a history of coronary artery disease) represented risk factors for coronary artery disease.

Written, informed consent was obtained from all the patients who participated in the study, and the ethics committee of our institution approved the study protocol. The investigation conformed to the principles outlined in the Declaration of Helsinki. ${ }^{7}$

\section{Immunohistochemical staining and analysis of} adrenomedullin

Sections ( $4 \mu \mathrm{m}$ thickness) cut from atherectomy specimens, fixed in $4 \%$ paraformaldehyde and embedded in paraffin, were stained with haematoxylin and eosin for morphological examination. Serial sections were deparaffinised and hydrated in $10 \mathrm{mM}$ phosphate buffered saline and then incubated in $3 \% \mathrm{H}_{2} \mathrm{O}_{2}$ in methanol for 20 minutes at room temperature to block endogenous peroxidase activity. The sections were washed in phosphate buffered saline (PBS) and incubated with a monoclonal antibody against synthetic human adrenomedullin (a ring structure) for 24 hours at 
$4^{\circ} \mathrm{C} .{ }^{8}$ In addition, intimal smooth muscle cells, macrophages, and intraplaque microvessels were identified using anti- $\alpha$ actin antibody (HHF35), anti-CD68 antibody, and anti-CD34 antibody, respectively (Dako Japan, Kyoto, Japan). Intervening washes with phosphate buffered saline (PBS) were followed by an incubation with EnVision+ (Dako Japan) for 30 minutes at room temperature. After further washes in PBS, the sections were incubated with $0.05 \% 3,3^{\prime}$ diaminobenzidine containing hydrogen peroxide, and counterstained with Meyer's haematoxylin.

Three independent observers who were blind to the patients identities manually counted the number of nuclei of adrenomedullin positive and negative cells in five high power fields $(\times 400)$ per specimen, as previously described. ${ }^{9}$ The results of these quantitative analyses are reported as the ratio $(\%)$ of positively stained cells among the five high power fields.

\section{Adrenomedullin mRNA measurement by real time quantitative polymerase chain reaction}

Individual atherectomy specimens from 14 of the 27 patients with UAP $(n=6)$ or SAP $(n=8)$ were frozen in liquid nitrogen and stored at $-80^{\circ} \mathrm{C}$. Total RNA $(1 \mu \mathrm{g})$, extracted from frozen specimens using isolation reagent ${ }^{10}$ (Trizol, Life Technologies, Rockville, Maryland, USA), was reverse transcribed employing SuperScript reverse transcriptase (GibcoBRL, Life Technologies, Gaithersburg, Maryland, USA) into cDNA. Human adrenomedullin and glyceraldehyde-3-phosphate dehydrogenase (GAPDH) mRNA concentrations were quantified by a novel quantitative polymerase chain reaction (PCR) method, real time quantitative PCR (Prism 7700 Sequence Detector, Applied Biosystems, Foster City, California, USA), as previously reported. ${ }^{11-13}$ The concentrations of adrenomedullin mRNA were compared after being normalised relative to those of GAPDH, as previously reported..$^{12}$

\section{Statistical analysis}

Data are expressed as mean (SEM). Probability values of $\mathrm{p}<0.05$ were considered significant. Fisher's exact test compared discrete variables (clinical and demographic data). A two tailed Student's $t$ test compared two samples (immunohistochemical and PCR data).

\section{RESULTS}

\section{Patient characteristics}

The initial baseline characteristics of patients with SAP and UAP are summarised in table 1. Risk factors for coronary artery disease did not differ significantly between SAP and UAP.

\section{Immunohistochemical staining of adrenomedullin}

Coronary atherectomy samples from patients with UAP were histologically rich in foam or stellate or spindle shaped cells (fig 1A). Many of these cells were positively stained for adrenomedullin (fig 1B). In contrast, the atherectomy samples from SAP were fibrous, containing some spindle shaped cells and very few foam cells (fig IC). Some of these cells were immunopositive for adrenomedullin (fig 1D). Many of the immunoreactive cells were intimal smooth muscle cells (anti- $\alpha$-actin antibody positive) and macrophages (anti-CD68 antibody positive), respectively (fig 2, panels A-D). Microvessels had proliferated occasionally in the UAP samples. The endothelial cells of these microvessels showed adrenomedullin immunopositivity (fig $2 \mathrm{E}$ and $2 \mathrm{~F}$ ). The mean numbers of adrenomedullin positive cells in five high power fields $(\times 400)$ per specimen were significantly higher in patients with UAP than in those with SAP ( 110 (13) $v 76$ (7); $\mathrm{p}<0.05$ ) (fig 3); and the ratio of adrenomedullin
Table 1 Baseline clinical characteristics of the study population

\begin{tabular}{|c|c|c|c|}
\hline Characteristics & $\operatorname{SAP}(n=12)$ & UAP $(n=15)$ & p Value \\
\hline Age (years) & $63(3)$ & $63(2)$ & 0.97 \\
\hline Male/female & $11 / 1$ & $14 / 1$ & $>0.99$ \\
\hline Systemic hypertension & 3 & 9 & 0.12 \\
\hline Hyperlipidaemia* & 4 & 8 & 0.44 \\
\hline Hyperuricaemia & 2 & 2 & $>0.99$ \\
\hline Diabetes mellitus & 4 & 6 & $>0.99$ \\
\hline Smoker & 3 & 6 & 0.68 \\
\hline Obesity† & 2 & 4 & 0.66 \\
\hline Family history $\ddagger$ & 1 & 2 & $>0.99$ \\
\hline \multicolumn{4}{|c|}{ Culprit lesion (narrowing $>50 \%$ ) } \\
\hline LAD & 10 & 13 & \\
\hline LMT & 2 & 0 & \\
\hline RCA & 0 & 2 & 0.39 \\
\hline Aspirin & 12 & 15 & $>0.99$ \\
\hline Statins & 3 & 5 & 0.70 \\
\hline \multicolumn{4}{|c|}{$\begin{array}{l}\text { Values are mean (SEM) or } \mathrm{n} \text {. } \\
\text { *Previous diagnosis of hyperlipidaemia or patient on lipid lowering } \\
\text { therapy } \\
\text { †Body mass index }>30 \mathrm{~kg} / \mathrm{m}^{2} \text {. } \\
\text { †A parent, sibling, or child with a history of coronary artery disease. } \\
\text { LAD, left anterior descending coronary artery; LMT, left main trunk; RCA, } \\
\text { right coronary artery; SAP, stable angina pectoris; UAP, unstable angina } \\
\text { pectoris. }\end{array}$} \\
\hline
\end{tabular}

positive to total cells was significantly higher in patients with UAP than in those with SAP (43.0 (2.2)\% v $34.2(2.0) \%$; $\mathrm{p}<0.01$ ) (fig 3).

\section{Expression of adrenomedullin mRNA}

The level of adrenomedullin mRNA expression normalised to that of GAPDH was significantly higher in UAP than in SAP (60.4 (16.9)\% v 9.7 (3.3)\%; p < 0.01) (fig 4).

\section{DISCUSSION}

This study shows first, that adrenomedullin immunoreactivity of the coronary plaque is present in macrophages, intimal smooth muscle cells, and proliferating microvessels; second, that the amount of adrenomedullin immunoreactivity is significantly higher in patients with UAP than with SAP; and third, that expression of adrenomedullin mRNA is greater in plaque from patients with UAP than with SAP. These results suggest that adrenomedullin is involved in the pathogenesis of plaque instability of human coronary atherosclerosis.

Previous studies have determined that adrenomedullin has multifunctional biological activities, including vasorelaxation, diuretic action, and inhibition of aldosterone secretion. ${ }^{2}$ Circulating adrenomedullin concentrations are raised in cardiovascular, endocrine, renal, and thrombotic diseases. $^{2}{ }^{14} 15$ Nakayama and colleagues reported that macrophages in human aortic atherosclerotic lesions, as well as endothelial cells and vascular smooth muscle cells, were immunopositive for adrenomedullin. ${ }^{16}$ However, few studies have addressed the possible role of adrenomedullin in the pathogenesis or process of atherosclerosis. Our present results are consistent with Nakayama's, but we are the first to observe adrenomedullin immunoreactivity in coronary atherosclerotic lesions.

Macrophages play a crucial role in atherogenesis and are highly activated in advanced atherosclerotic lesions. ${ }^{4}$ Macrophage-rich areas are more common in atheromatous plaque, especially in its shoulder regions, among patients with UAP. ${ }^{17}$ Activated macrophages express inflammatory cytokines and matrix metalloproteinases which might induce plaque instability. ${ }^{48}$ Thus macrophage-rich lesions are considered a rupture prone region of atheromatous plaque, capable of causing acute coronary syndromes. ${ }^{6}{ }^{19}$ Cultured or 

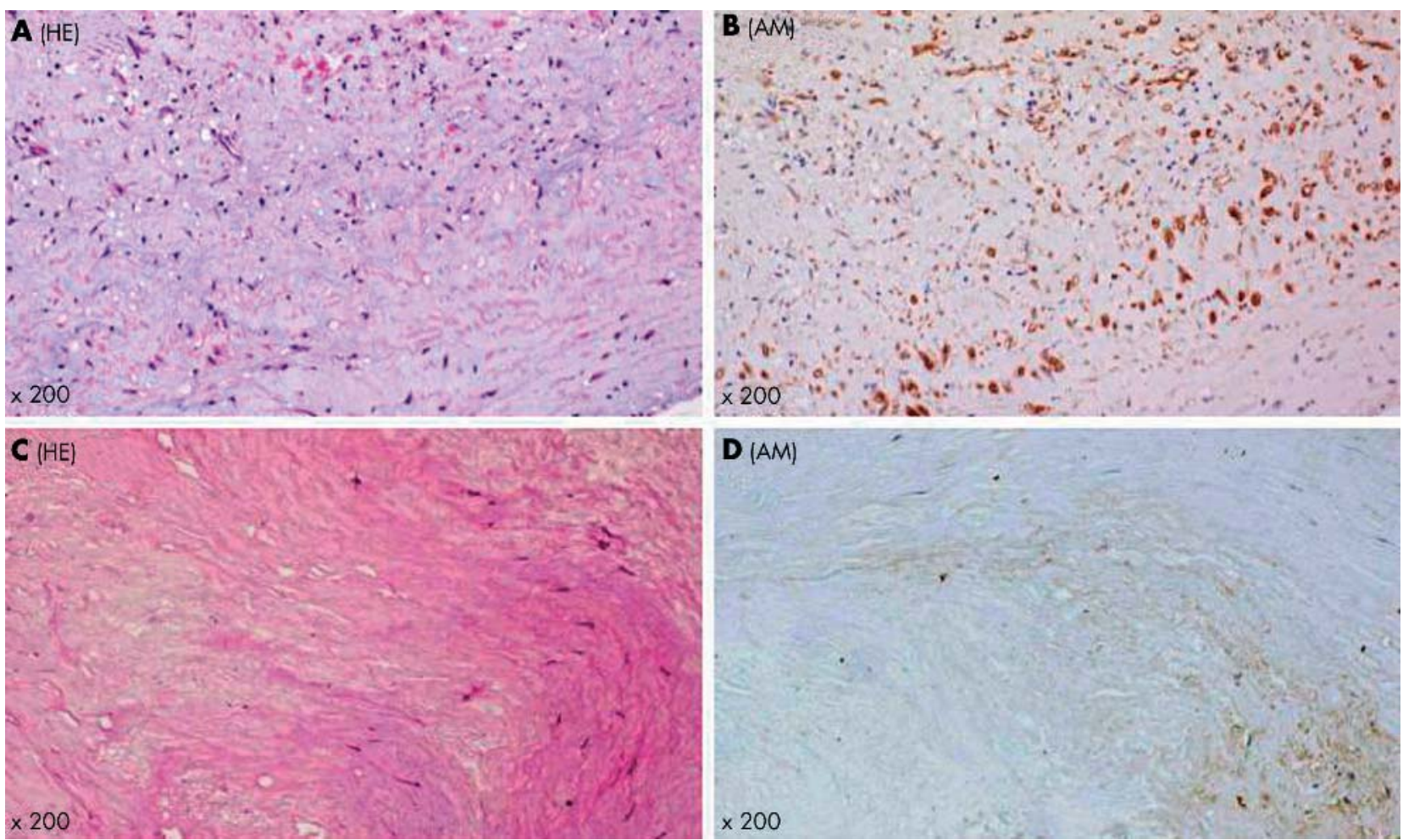

Figure 1 Representative histological features of atherectomy samples from patients with unstable angina pectoris (UAP) and stable angina pectoris (SAP). Foam cells and spindle cells accumulate in an atherectomy sample from a patient with UAP (A). Many of these cells (60\% in this field) are positively stained for adrenomedullin (B). Plaque tissue from a patient with SAP is fibrous (C), and immunoreactivity for adrenomedullin is weak in some spindle cells (30\% in this field) (D). AM, adrenomedullin; HE, haematoxylin and eosin stain.
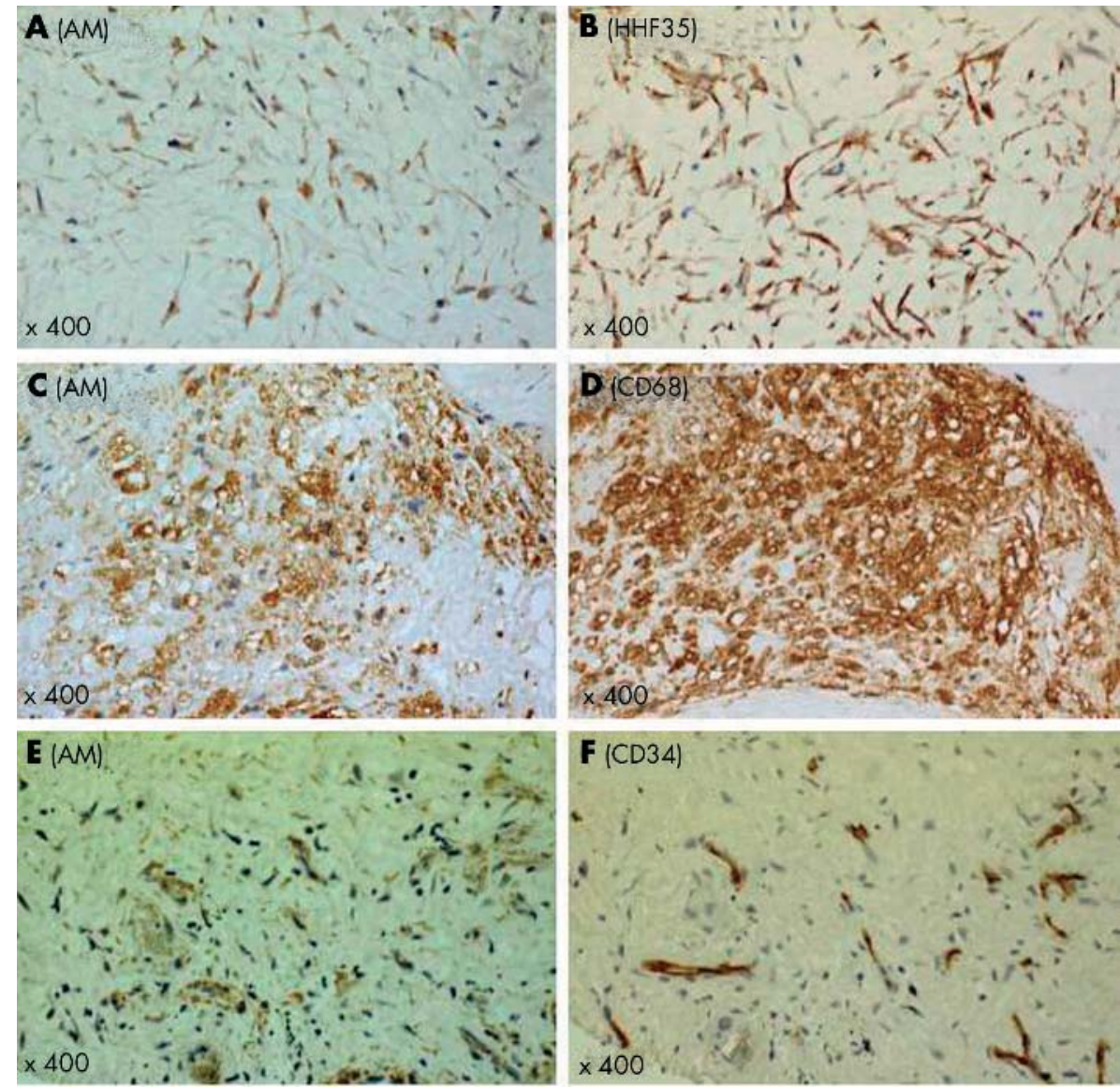
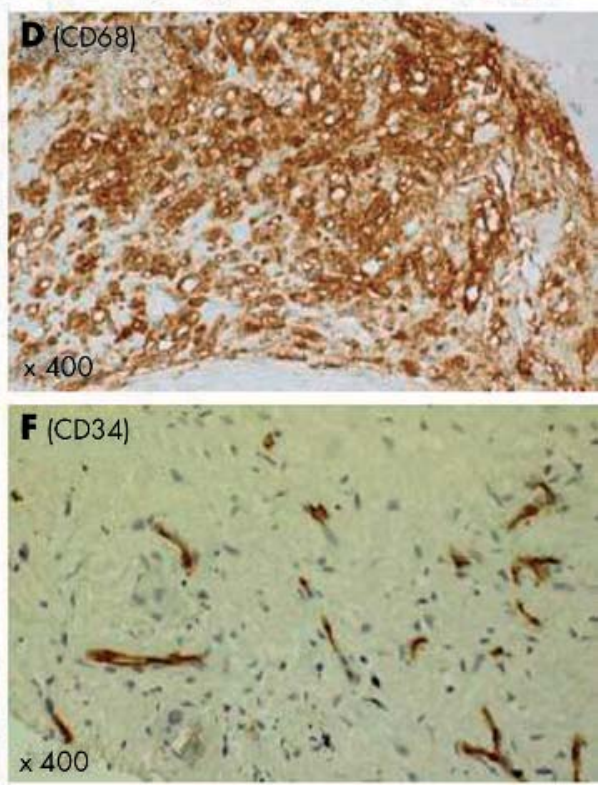

Figure 2 Representative

immunohistochemical features of atheromatous plaque in a patient with unstable angina pectoris. Many adrenomedullin positive stellate or spindle shaped cells are intimal smooth muscle cells (A, B). Adrenomedullin positive foam cells are macrophages (C, D). In neovascularised microvessels, endothelial cells are immunopositive for adrenomedullin (E, F). AM, adrenomedullin. 


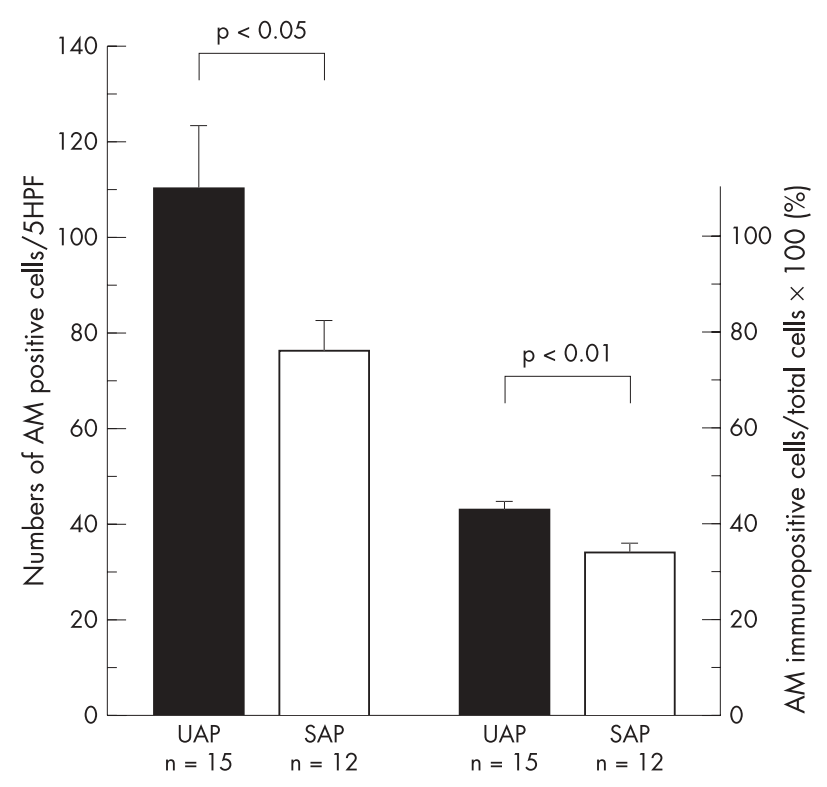

Figure 3 The numbers of adrenomedullin positive cells and ratio of adrenomedullin positive to total cells in plaques from patients with unstable angina pectoris (UAP) and stable angina pectoris (SAP). The numbers of adrenomedullin positive cells in five high power fields $(\times 400)$ per specimen are significantly higher in patients with UAP than in patients with SAP (mean (SEM), 110 (13) v 76 (7); $p<0.05$ ). The ratio of adrenomedullin positive to total cells in atherectomy samples is higher in patients with UAP than with SAP (43.0 (2.2)\% v 34.2 (2.0)\%; $p<0.01)$. AM, adrenomedullin.

peritoneal macrophages produce and secrete adrenomedullin, ${ }^{20}$ and both types of cell are stimulated by lipopolysaccharide, interferon- $\gamma$, and tumour necrosis factor $\alpha .^{21}{ }^{22}$ Moreover, adrenomedullin expression and secretion by the monocyte-macrophage lineage can be regulated by the degree of differentiation into macrophages, ${ }^{5}{ }^{16}$ and adrenomedullin inhibits the release of chemoattractants from macrophages. ${ }^{23}$ These findings suggest that adrenomedullin secreted from macrophages in atherosclerotic lesions could inhibit the progression of atherosclerosis and prevent plaque disruption. However, we could not define the pathophysiological role of adrenomedullin expressed in macrophages in the present study.

Vascular smooth muscle cells in atherosclerotic lesions were also positively stained for adrenomedullin in this study. Intimal smooth muscle cells have unique properties that are not found in medial cells, such as high mitotic activity and growth factor receptor expression, ${ }^{24}{ }^{25}$ and the phenotypes of intimal smooth muscle cells could be different from those of medial smooth muscle cells. ${ }^{4}$ Although the roles of adrenomedullin expressed in intimal smooth muscle cells have not been intensively studied, recent reports suggest that adrenomedullin suppresses the proliferation and migration of cultured vascular smooth muscle cells $s^{26}$ and endothelin production in cultured vascular smooth muscle cells. ${ }^{28}$ Furthermore, local adrenomedullin gene delivery significantly inhibits arterial thickening, promotes re-endothelialisation, and increases vascular CGMP concentrations in the rat artery after balloon angioplasty. ${ }^{29}$ Vascular injury is obvious and concomitant with increased oxidative stress induced by angiotensin II/salt loading in knockout adrenomedullin +/mice in which only the adrenomedullin peptides are disrupted. $^{30}$ These lines of evidence suggest that adrenomedullin plays a protective role against the development of atherosclerosis. $^{31}$

Plasma adrenomedullin concentrations of the coronary sinus and peripheral vein increase immediately after

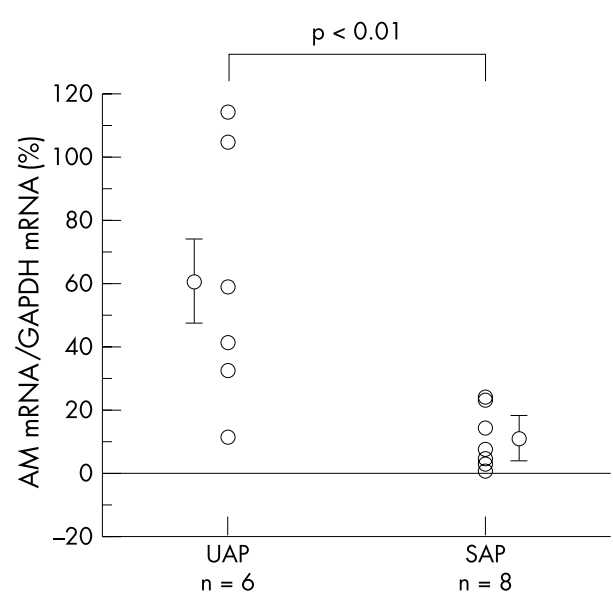

Figure 4 Adrenomedullin mRNA expression level in plaques from patients with unstable angina pectoris (UAP) and stable angina pectoris (SAP). The level of adrenomedullin mRNA expression in plaque is significantly higher in patients with UAP than with SAP $(60.4$ (16.9)\% v 9.7 (3.3)\%; $p<0.01$ ). AM, adrenomedullin.

percutaneous transluminal coronary angioplasty. ${ }^{32}{ }^{33}$ The increased concentrations of plasma adrenomedullin are thought to originate from injured atheromatous plaque or from the ischaemic myocardium. Levels of adrenomedullin immunoreactivity and mRNA are also high in human failed left ventricular muscle, and plasma adrenomedullin is increased in chronic heart failure and acute myocardial infarction..$^{34-36}$ Our results also suggest that some of the increased plasma adrenomedullin could be released from the injured atheromatous plaque by percutaneous coronary intervention, especially in patients with UAP. Further investigation is needed to clarify this hypothesis.

The limitations of our study are the small number of subjects, the lack of randomisation to a control group, and a bias towards coronary lesions suitable for an atherectomy procedure rather than balloon angioplasty or stent deployment. Nonetheless, our paper is the first to show that levels of adrenomedullin immunoreactivity and mRNA expression are higher in atherectomy samples from patients with UAP than with SAP. Although we could not determine the roles of adrenomedullin in atherosclerotic lesions in this study, our results suggest that adrenomedullin may be involved in plaque instability in an autocrine or paracrine manner.

\section{ACKNOWLEDGEMENTS}

This study was supported by the grants-in-aid for scientific research (C-2) (Nos 14570153 and 15590305) and for the 21st Century COE Program (Life Science) from The Ministry of Education, Science, Sports, and Culture, Japan.

\section{Authors' affiliations}

T Ishikawa, T Imamura, K Ito, S Hara, H Date, T Eto, First Department of Internal Medicine, Miyazaki Medical College, University of Miyazaki, Miyazaki, Japan

K Hatakeyama, Y Asada, First Department of Pathology, Miyazaki Medical College, University of Miyazaki

Y Shibata, Miyazaki Medical Association Hospital, Miyazaki

Y Hikichi, Shin-Koga Hospital, Kurume, Japan

\section{REFERENCES}

1 Kitamura K, Kangawa K, Kawamoto M, et al. A novel hypotensive peptide isolated from human pheochromocytoma. Biochem Biophys Res Commun 1993; 192:553-60.

2 Eto T. A review of the biological properties and clinical implications of adrenomedullin and proadrenomedullin $\mathrm{N}$-terminal 20 peptide (PAMP), hypotensive and vasodilating peptides. Peptides 2001;22:1693-711. 
3 Asada $Y$, Hara S, Marutsuka $K$, et al. Novel distribution of adrenomedullinimmunoreactive cells in human tissues. Histochem Cell Biol $1999 ; 112: 185-91$.

4 Ross $\mathbf{R}$. The pathogenesis of atherosclerosis: an update. N Engl J Med 1986; 314:488-500.

5 Tomoda $Y$, Isumi $Y$, Katafuchi $T$, et al. Regulation of adrenomedullin secretion from cultured cells. Peptides $2001 ; 22: 1783-94$.

6 Libby P. Molecular bases of acute coronary syndromes. Circulation 1995;91:2844-50.

7 World Medical Association. Declaration of Helsinki. Recommendations guiding physicians in biomedical research involving human subjects. Cardiovasc Res 1997;35:2-3.

8 Ohta H, Tsuji T, Asai S, et al. One-step direct assay for mature-type adrenomedullin with monoclonal antibodies. Clin Chem 1999:45:244-51.

9 Kearney M, Pieczek A, Haley L, et al. Histopathology of in-stent restenosis in patients with peripheral artery disease. Circulation 1997;95:1998-2002.

10 Chomczynski P. A reagent for the single-step simultaneous isolation of RNA DNA and protein from cell and tissue samples. BioTechniques 1993; 15:536-7

11 Heid CA, Stevens J, Livak KJ, et al. Real time quantitative PCR. Genome Res 1996;6:986-94

12 Uemura T, Kato J, Kuwasako K, et al. Aldosterone augments adrenomedullin production without stimulating pro-adrenomedullin $\mathrm{N}$-terminal 20 peptide secretion in vascular smooth muscle cells.J Hypertens 2002:20:1209-14.

13 Nagoshi Y, Kuwasako K, Ito K, et al. The calcitonin receptor-like receptor/ receptor activity-modifying protein 1 heterodimer can function as a calcitonin gene-related peptide-(8-37)-sensitive adrenomedullin receptor. Eur J Pharmacol 2002:450:237-43.

14 Ishimitu N, Nishikimi T, Saito Y, et al. Plasma levels of adrenomedullin, a newly identified hypotensive peptide, in patients with hypertension and renal failure. J Clin Invest 1994;94:2158-61.

15 Kohno M, Hanehira T, Kano H, et al. Plasma adrenomedullin concentrations in essential hypertension. Hypertension 1996;27:102-7.

16 Nakayama M, Takahashi K, Murakami O, et al. Adrenomedullin in monocytes and macrophages: possible involvement of macrophage derived adrenomedullin in atherogenesis. Clin Sci 1999;97:247-51.

17 Moreno PR, Falk EF, Palacios IF, et al. Macrophage infiltration in acute coronary syndromes. Implications for plaque rupture. Circulation 1994:90:775-8.

18 Galis ZS, Sukhova GK, Lark MW, et al. Increased expression of matrix metalloproteinases and matrix degrading activity in vulnerable regions of human atherosclerotic plaques. J Clin Invest 1994:64:2493-503.

19 van der Wal AC, Becker AE. Atherosclerotic plaque rupture - pathologic basis of plaque stability and instability. Cardiovasc Res 1999;41:334-44.

20 Kubo A, Minamino N, Isumi Y, et al. Production of adrenomedullin in macrophage cell line and peritoneal macrophage. J Biol Chem 1998:273:16730-8.

21 Sugo S, Minamino N, Shoji $\mathrm{H}$, et al. Production and secretion of adrenomedullin from vascular smooth muscle cells: augmented production by tumor necrosis factor-alpha. Biochem Biophys Res Commun 1994;203:719-26.

22 Sugo S, Minamino N, Shoji H, et al. Interleukin-1, tumor necrosis factor and lipopolysaccharide additively stimulate production of adrenomedullin in vascular smooth muscle cells. Biochem Biophys Res Commun 1995;207:25-32.

23 Kamoi $\mathrm{H}$, Kanazawa $\mathrm{H}$, Hirata K, et al. Adrenomedullin inhibits the secretion of cytokine-induced neutrophil chemoattractant, a member of the interleukin-8 family, from rat alveolar macrophages. Biochem Biophys Res Commun 1995;211:1031-5.

24 Majesky MW, Reidy MA, Bowen-Pope DF, et al. PDGF ligand and receptor gene expression during repair of arterial injury. J Cell Biol 1990;111:2149-58

25 Olson NE, Chao S, Lindner V, et al. Intimal smooth muscle cell proliferation after balloon catheter injury: the role of basic fibroblast growth factor. Am J Pathol 1992;140:1017-23.

26 Kano H, Kohno M, Yasunari K, et al. Adrenomedullin as a nove antiproliferative factor of vascular smooth muscle cells. J Hypertens 1996; 14:209-13.

27 Horio T, Kohno M, Kano $\mathrm{H}$, et al. Adrenomedullin as a novel antimigration factor of vascular smooth muscle cells. Circ Res 1995:77:660-4.

28 Kohno $M$, Kano $\mathrm{H}$, Horio $T$, et al. Inhibition of endothelin production by adrenomedullin in vascular smooth muscle cells. Hypertension 1995; $25: 1185-90$

29 Chao J, Kato K, Zhang JJ, et al. Human adrenomedullin gene delivery protects against cardiovascular remodeling and renal injury. Peptides 2001;22:1731-7.

30 Shimosawa T, Shibagaki Y, Ishibashi K, et al. Adrenomedullin, an endogenous peptide, counteracts cardiovascular damage. Circulation 2002;105:106-11.

31 Imai Y, Shindo T, Maemura K, et al. Resistance to neointimal hyperplasia and fatty streak formation in mice with adrenomedullin overexpression. Arterioscler Thromb Vasc Biol 2002;22:1310-15.

32 Etoh T, Doi H, Hanada Y, et al. Cardiac secretion of adrenomedullin by percutaneous transluminal coronary angioplasty. Horm Metab Res 1997;29:530-1.
33 Kemal Erol M, Genc Y, Kiziltunc A, et al. Increased plasma adrenomedullin in patients undergoing percutaneous transluminal coronary angioplasty. Swiss Med Wkly 2001;131:50-3.

34 Kobayashi K, Kitamura K, Etoh T, et al. Increased plasma adrenomedullin levels in chronic congestive heart failure. Am Heart J 1996;131:994-8.

35 Kobayashi K, Kitamura K, Hirayama N, et al. Increased plasma adrenomedullin in acute myocardial infarction. Am Heart $J$ 1996;131:676-80.

36 Jougasaki $M$, Wei CM, McKinley $L$, et al. Elevation of circulating and ventricular adrenomedullin in human congestive heart failure. Circulation 1995:92:286-9.

\section{WEB TOP 10}

www.heartinl.com

These articles scored the most hits on Heart's website during July 2004

1 Will oral antithrombin agents replace warfarin?

PR Sinnaeve, FJ Van de Werf

August 2004;90:827-8. (Editorials)

2 Management of dyslipidaemia

GR Thompson

August 2004;90:949-55. (Education in Heart)

3 Management of acute coronary syndromes: an update KAA Fox

June 2004;90:698-706. (Education in Heart)

4 B type natriuretic peptide testing: where are we now? MR Cowie

July 2004;90:725-6. (Editorial)

5 Management and follow up of prosthetic heart valves C Seiler

July 2004;90:818-24. (Education in Heart)

6 Role of oral anticoagulation in management of atrial fibrillation

E Crystal, SJ Connolly

July 2004;90:813-7. (Education in Heart)

7 Anatomy of coronary disease in diabetic patients: an explanation for poorer outcomes after percutaneous coronary intervention and potential target for intervention KP Morgan, A Kapur, KJ Beatt

July 2004;90:732-8. (Review)

8 Risk stratification in acute coronary syndrome: focus on unstable angina/non-ST segment elevation myocardial infarction

$R$ Bugiardini

July 2004;90:729-31. (Editorial)

9 British Cardiac Society Working Group on the definition of myocardial infarction

KAA Fox, J Birkhead, R Wilcox, C Knight, J Barth June 2004;90:603-9.

10 Joint British recommendations on prevention of coronary heart disease in clinical practice

December 1998;80:1-29.

Visit the Heart website for hyperlinks to these articles, by clicking on "Top 10 papers"

www.heartinl.com 